\section{Impact of wildfire on the edaphic microarthropod community in a Pinus pinaster forest in central Italy}

\author{
Chiara Lisa ${ }^{(1)}$, Donatella Paffetti ${ }^{(2)}$, Susanna Nocentini ${ }^{(1)}$, \\ Enrico Marchi ${ }^{(1)}$, Francesca Bottalico ${ }^{(1)}$, Silvia Fiorentini ${ }^{(1)}$, \\ Davide Travaglini ${ }^{(1)}$
}

The purpose of this study was to investigate the response of the soil microarthropod community to wildfire in forest ecosystems. The edaphic microarthropod communities of pine stands burned in 2001, in 2009, both in 2001 and in 2009, in 2012 were compared to an area never burned. Sampling was conducted in the spring and autumn of 2011 and 2012 in the areas burned in 2001, in 2009 and those never burned, while in the area burned in 2012, soil samples were collected in March (10 days after fire), June and September. The abundance and biodiversity of the microarthropod community were assessed. A multitemporal analysis was also carried out to assess the effect of fire on soil microarthropod abundance 5 months, 2-3 years and 10-11 years after fire. The results showed that the abundance of edaphic microarthropod communities decreased dramatically in areas burned twice, but also in areas burned once in 2009 and five months after the fire in the area burned in 2012. Different taxonomic groups did not seem to respond to fire in the same way, some taxa being more sensitive than others. Pseudoscorpionida decreased in both the shortand the long-term, while Diplopoda, Thysanoptera and Symphyla showed a reduction in the intermediate- and long-term. In the short-term, Diptera and Coleoptera larvae appeared to be the most influenced taxonomic groups. Our study shows that biomonitoring is a valuable tool to investigate the reaction of forest ecosystems to fire, and that edaphic microarthropods can provide interesting answers about the direct and indirect effects of fire on soil.

Keywords: Biomonitoring, Microarthropod Community, Forest Fires, Pinus pinaster Aiton

\begin{abstract}
Introduction
Understanding ecosystem responses to disturbance at different scales is fundamental to develop sound strategies for forest management and nature conservation (Kremen 2005). To this end, biomonitoring - i.e., the analysis of the reactive components of ecosystems in response to environmental changes to assess deviations from the normal situation (Spellerberg 1991, Nimis et al. 2002) - and ecological indicators can be used to
\end{abstract}

quantify the magnitude of stress, the degree of exposure or the ecological response to stresses (Dale \& Beyeler 2001), thereby providing a simple and efficient method to assess the composition, structure and function of complex ecological systems (Karr 1991).

Fire is one of the most important disturbances in many natural and semi-natural ecosystems worldwide (Granström 2001), including the Mediterranean Region (Pausas 2004). Fire also has an ecological role in in-

(1) Department of Agricultural, Food and Forestry Systems, University of Florence, v. San Bonaventura 13, I-50145 Florence (Italy); (2) Department of Agriculture, Food and Environmental Sciences, University of Florence, p.le delle Cascine 28, I-50144 Florence (Italy)

@, Enrico Marchi (enrico.marchi@unifi.it)

Received: Jul 21, 2014 - Accepted: Jan 27, 2015

Citation: Lisa C, Paffetti D, Nocentini S, Marchi E, Bottalico F, Fiorentini S, Travaglini D, 2015. Impact of wildfire on the edaphic microarthropod community in a Pinus pinaster forest in central Italy. iForest 8: 874-883 [online 2015-05-05] URL: http://www. sisef.it/iforest/contents/?id=ifor1404-008

Communicated by: Massimo Faccoli fluencing ecosystem biodiversity and guaranteeing the conservation of a variety of habitats (Hadjibiros 2001, Moreira et al. 2001, Blondel et al. 2010) and changing landscapes (Gillson 2009). The soil biota is one of the first soil components to respond to fire exposure, as fire alters the species composition and decreases the zoocenotic density (Bezkorovainaya et al. 2007).

Fire may have direct or indirect effects on soil fauna. One of the principal direct impacts on the edaphic microarthropod community is the exposure of forest fauna to high temperatures, which can cause alterations in species composition and decrease the abundance of some taxonomic groups (Sgardelis et al. 1995, DeBano et al. 1998, Bezkorovainaya et al. 2007). Contrastingly, some authors claimed that the direct effects of fire on most soil vertebrates are minimal (Ream 1981, Neary et al. 1999). Indirect fire impacts include changes in habitat and food availability for these organisms. After a fire, alterations of hydrothermal conditions, litter mass and $\mathrm{pH}$ have an impact on animal survival, particularly the stenoecious species which suffer high temperatures as well as light and moisture extremes, with subsequent habitat loss (Roloff et al. 2005, Bezkorovainaya et al. 2007). While some changes of the edaphic community can be irrelevant in the short-term after fire, the subsequent postfire, aboveground succession can determine changes in soil fauna, affecting the age and trophic structure of soil animals (Bezkorovainaya et al. 2007).

Edaphic microarthropods play an important role in regulating the rate of decomposition (Wallwork 1983, Seastedt 1984) and nutrient cycling (Heneghan \& Bolger 1998) through interactions with the microbial and fungal communities (Seastedt 1984, Seastedt \& Crossley 1984, Lussenhop 1992), and they also contribute to soil structure and humus formation (Wallwork 1983, Norton 1985, Striganova 2000). For all these reasons, the preservation of soil biodiversity should be considered an integral component of forest management practices (Marshall 2000). Therefore, understanding the reaction of a forest to fire and, in particular, how it impacts edaphic microarthropods is important, even though subtle variations in the structure of edaphic communities and their spatial distribution have been given little consideration in the macroscopic approach to ecosystem functionality (Heneghan \& Bolger 1998).

Biological indicators are often more sensitive to change than other indicators, and they could be used in environmental monitoring and assessment (Bastida et al. 2008). However, studies on the impact of fire on edaphic microarthropod communities are still limited and focus mainly on the two most numerous groups in soil, such as mites (Acari) and 


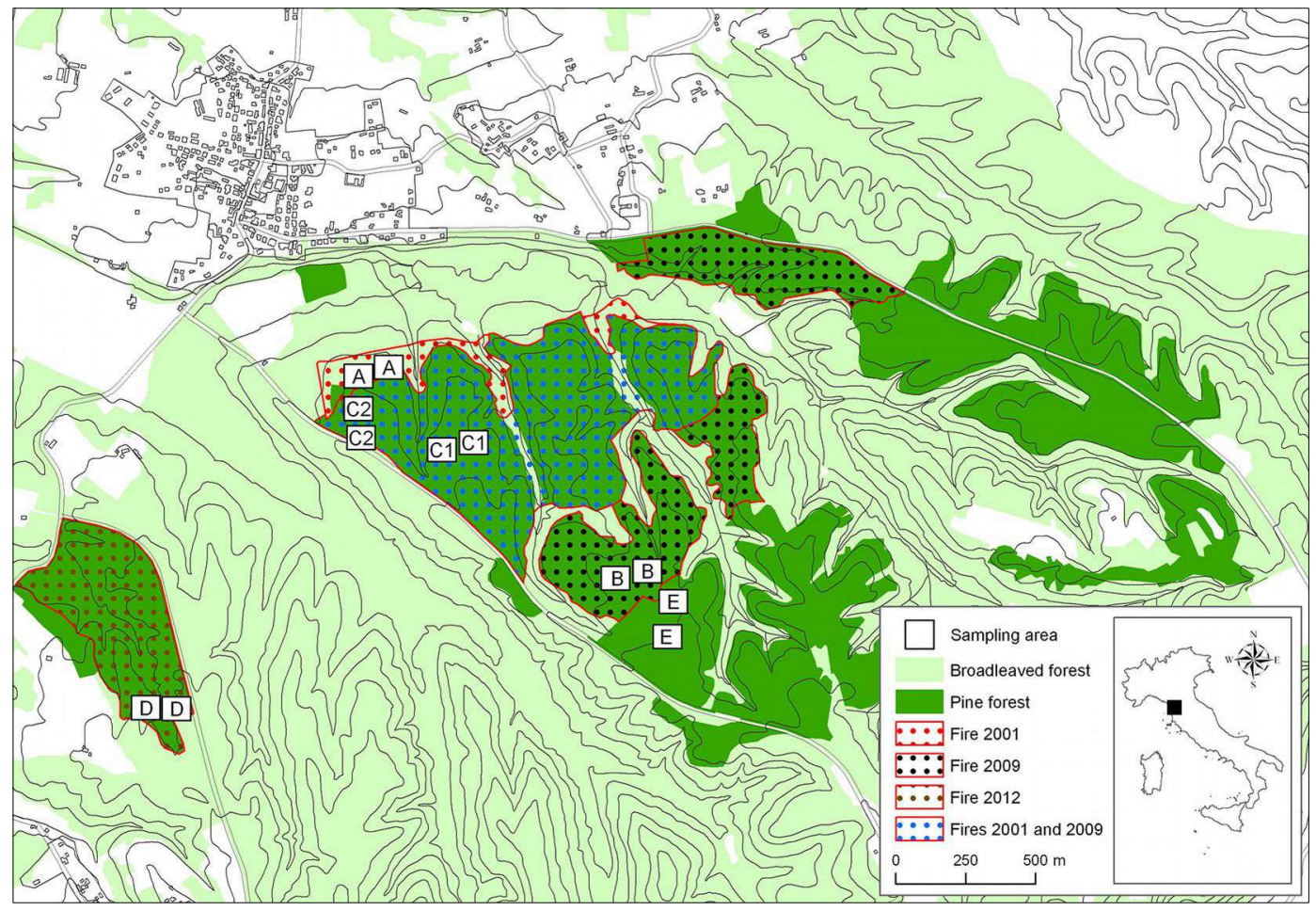

Fig. 1 - Map of the study area.

springtails (Collembola - Dress \& Boerner 2003, Camann et al. 2008, Grabcizynska et al. 2009, Malmström 2010, 2012, Huebner et al. 2012, Cuchta et al. 2012a, 2012b) Studies on the impact of fire on edaphic microarthropod communities that consider other taxa are few, and they are mostly limited to cases of prescribed fire (Wikars \& Schimmel 2001, Moretti et al. 2004, Coleman \& Rieske 2006, Bezkorovainaya et al. 2007, Malmström et al. 2008, Vincent et al 2009, Silveira et al. 2010). It is also worth noting that many of these experiments are based on data simulated in the laboratory, while the number of studies based on real data collected in the forest is low, and (at least in the Mediterranean region) such studies have focused on a relatively small number of taxa. For instance, some authors have studied the effect of fire on only one taxon, such as Myriapoda (Saulnier \& Athias-Binche 1986, García-Ruiz 2001, Tajovský 2002, Trucchi et al. 2009) or edaphic carabids (Santalla et al. 2002), while few studies have examined multiple edaphic groups (Broza et al. 1993, Sgardelis et al. 1995, Broza \& Izhaki 1997).

In this study, we investigated the response to fire of the whole edaphic microarthropod community in Mediterranean pine stands. We also conducted a multitemporal analysis to assess the effect of fire frequency on soil microarthropod abundance. The aims were: (1) to monitor microarthropod abundance and the shift in biodiversity in forest areas burned in 2001, 2009 and 2012; (2) to assess the impact of fire frequency on the microarthropod community composition in forest areas burned in 2001 and again in 2009; (3) to evaluate the microarthropod composition recovery over time, taking into account three time intervals after the fires, hereafter indicated as short- (5 months), intermediate- (23 years) and long- (10-11 years) term intervals.

\section{Materials and methods}

\section{Study area}

The experimental site is located in central Italy (Tuscany) in the hilly district of Cerbaie, $50 \mathrm{~km}$ east of Pisa, including the Montefalcone National Nature Reserve $\left(43^{\circ} 44^{\prime}\right.$ $35^{\prime \prime} \mathrm{N}, 10^{\circ} 42^{\prime} 25^{\prime \prime} \mathrm{E}$ ) and a surrounding area $\left(43^{\circ} 44^{\prime} 08^{\prime \prime} \mathrm{N}, 10^{\circ} 41^{\prime} 51^{\prime \prime} \mathrm{E}\right.$ - Fig. 1).

The area is characterized by a temperate climate (Köppen 1936, Sbragia 2004) with a 14-15 ${ }^{\circ} \mathrm{C}$ mean annual temperature and

Tab. 1 - Duration, burned area and burned biomass of the forest fires where the impact on edaphic microarthropod communities was analysed. (na): not available.

\begin{tabular}{lccc}
\hline Fire & $\begin{array}{c}\text { Burned area } \\
\text { (hectares) }\end{array}$ & $\begin{array}{c}\text { Duration } \\
\text { (hour) }\end{array}$ & $\begin{array}{c}\text { Wood biomass } \\
\left.\text { burned } \mathbf{( m}^{\mathbf{3}}\right)\end{array}$ \\
\hline August 2001 & 70 & 47.0 & 16200 \\
August 2009 & 130 & 53.0 & na \\
March 2012 & 15 & 3.5 & na \\
\hline
\end{tabular}

1000-1150 mm mean annual precipitation, concentrated in autumn and winter i.e., it has a humid and sub-humid climate type according to Thornthwaite's classification (Thornthwaite 1948, Sbragia 2004). Altitude varies between 45 and $114 \mathrm{~m}$ a.s.l. The study areas were located on quite flat terrain with very limited altitudinal differences (less than 20 $\mathrm{m}$ among the areas). Prevailing winds in the area are from the north and southwest. The geological setting is a sand and coastal conglomerate (Pliocene), and soils are loose, medium-deep, with a mainly acidic reaction, and variable in texture, drainage and pore space (Olivari 2004).

Forest cover is dominated by the maritime pine (Pinus pinaster Aiton) in the higher zones and mixed oaks (Quercus cerris L. and $Q$. petraea Liebl.) in the lower and more humid areas. Coniferous stands are 80-85 years old, with pine in the dominant layer and butcher's broom (Ruscus aculeatus L.), holly (Ilex aquifolium L.), cornelian cherry (Cornus mas L.), heathers (Erica spp.), juniper (Juniperus communis L.), brambles (Rubus spp.), brooms (Cytisus scoparius (L.) Link), laurel (Laurus nobilis L.), cistus (Cistus spp.) and ferns (Pteridium aquilinum (L.) Kuhn) in the shrub layer.

In the last several years, three fires have occurred in the area. About 70 hectares (ha) of pine forest burned in August 2001; in August 2009 another fire burned about 130 ha of pine forest, including 70 ha already burned in 2001 (Nocentini et al. 2011). In March 2012, a fire burned 15 ha of pine forest close to the areas burned in 2001 and 2009 (Fig. 1). Data about the duration of the 
Fig. 2 - View of the burned and unburned areas analyzed in this study.

(A): area burned in 2001; (B): area

burned in 2009: (C), area burned twice in 2001 and in 2009; (D): area burned in 2012; (E): area not affected by fire (control area).

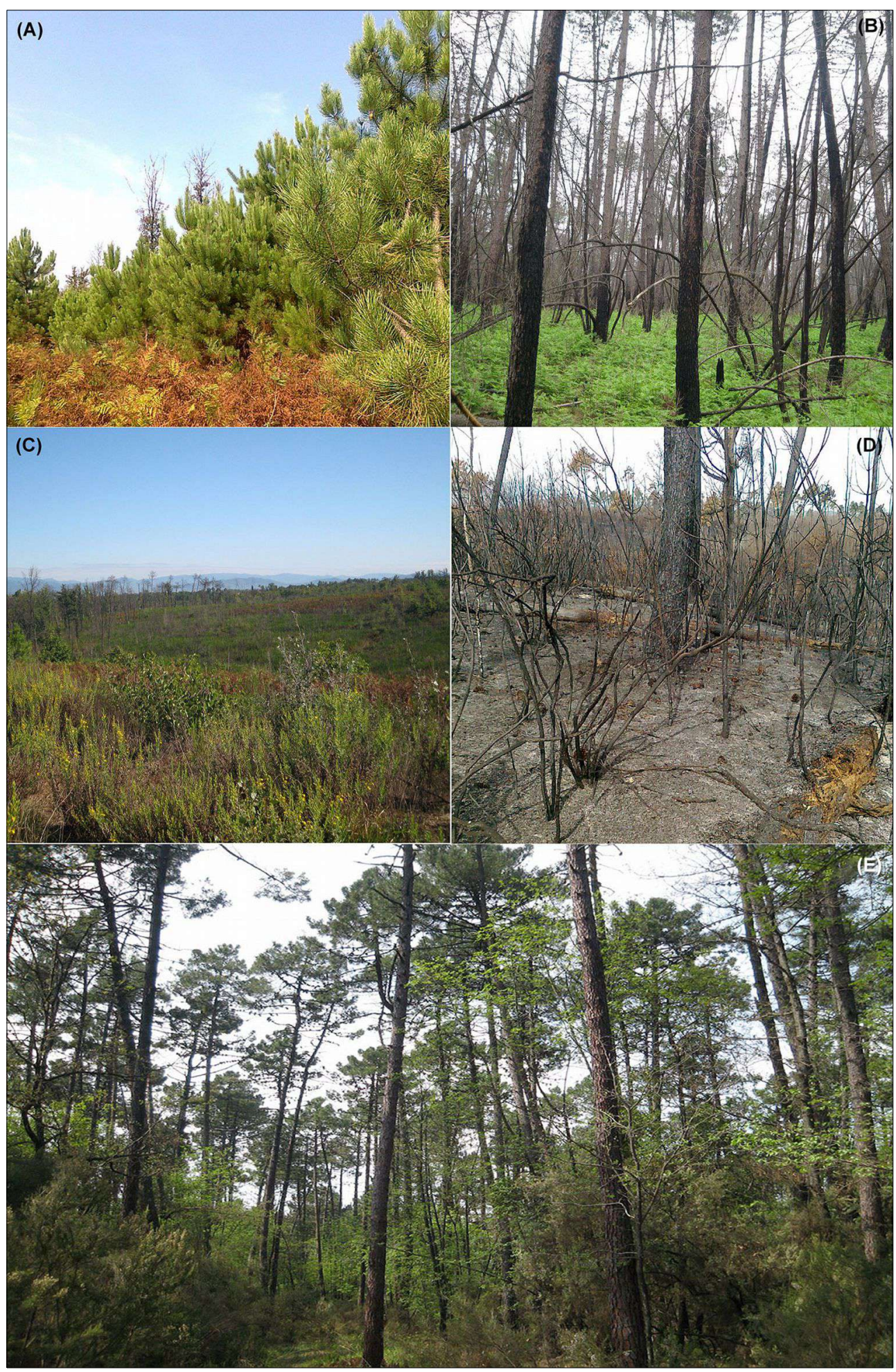

fires, the burned areas, and burned biomass were registered by the National Forest Service (Tab. 1). The fires spread mainly as passive and active crown fires involving duff, litter, shrubs and the tree canopy. Detailed data on fire severity in the study areas were not available, but based on direct field observations by fire managers, it was possible to estimate that the severity of all fires ranged from "moderate or severe surface burn" to "deep burning or crown fire", according to Keeley (2009). In the area burned in 2001, natural pine regeneration (around 10 years old) has set in, together with many shrubs and ferns. In the area burned in 2009, there are burned pine snags and ferns. The areas burned both in 2001 and in 2009 are covered mainly by nitrogen-fixing species, such as brooms (C. scoparius Link), cistus (Cistus spp.), heathers (Erica spp.) and fire moss (Ceratodon purpureus Brid.). In the area burned in 2012, there are numerous firedamaged trees and dead trees, with the understorey completely destroyed by fire; the terrain is covered by grey and white ash (Fig. 2). 
Tab. 2 - Dates of sampling in each treatment.

\begin{tabular}{lccccccc}
\hline \multirow{2}{*}{ Sampling area } & \multicolumn{7}{c}{ Sampling dates } \\
\cline { 2 - 8 } & \multicolumn{2}{c}{2011} & \multicolumn{5}{c}{2012} \\
\cline { 2 - 8 } & Spring Autumn & Spring & Autumn & 23 Mar 25 Jun 18 Sep \\
\hline A (burned in 2001) & - & $\times$ & $\times$ & $\times$ & - & - & - \\
B (burned in 2009) & $\times$ & $\times$ & $\times$ & $\times$ & - & - & - \\
C (burned in 2001 and 2009) & $\times$ & $\times$ & $\times$ & $\times$ & - & - & - \\
D (burned in March 2012) & - & - & - & - & $\times$ & $\times$ & $\times$ \\
E (control - never burned) & $\times$ & $\times$ & $\times$ & $\times$ & - & - & - \\
\hline
\end{tabular}

\section{Ground data}

Sampling was conducted in the following areas:

- an area that burned in 2001 (A);

- an area that burned in 2009 (B);

- an area that burned twice, in 2001 and again in 2009 (C);

- an area that burned in 2012 (D);

- an area not affected by fire (Control E).

In each area, two square plots $(7.1 \times 7.1 \mathrm{~m})$ were placed so as to be homogeneous in terms of site aspect, forest cover and soil characteristics. In the area burned twice (C), two sub-areas with very similar types of vegetation $(\mathrm{C} 1$ and $\mathrm{C} 2)$ were selected to provide more representative information of the area's apparent higher soil variability, and also because large surfaces burned in 2001 and in 2009. In each sub-area, two plots were etablished (Fig. 1). In each plot, three $10 \times 10 \times 10 \mathrm{~cm}$ soil samples were collected along a $10-\mathrm{m}$ transect (placed along the plot diagonal) for the identification of edaphic microarthropod communities. The $x, y$ coordinates of all sampling points (36) were recorded using a GPS receiver Trimble Juno 3B Handheld with 2-5 m positional accuracy.

Soil samples were collected in the spring and autumn of 2011 and 2012 for sampling areas A, B, C and control E, and at three different dates after the fire in the area that burned in 2012 (D - Tab. 2). The soil layer was also analysed for carbon content and $\mathrm{pH}$ in all plots by collecting three randomly selected samples. The samples were collected using a metal cylinder $(10-\mathrm{cm}$ long with a 5 $\mathrm{cm}$ inner diameter) after litter removal. Soil temperature and moisture were measured at a depth of $10 \mathrm{~cm}$ using a moisture meter ( $\mathrm{HH} 2$ - Moisture Meter - Readout Unit; Delta-T Devices) after sample collection.

\section{Data Analysis}

\section{Laboratory analysis}

Edaphic microarthropods were extracted from soil samples using a Berlese Tüllgren funnel (Berlese 1905, Tüllgren 1918) with an exposition of 7 days; then microarthropods were preserved in $75 \%$ ethanol $(\mathrm{v} / \mathrm{v})$. Extracted soil fauna were counted and identified to the Order taxonomic level using a stereomicroscope with a magnification of
$40 \times$.

The soil $\mathrm{pH}$ and carbon content were also estimated. The soil $\mathrm{pH}$ was determined with $\mathrm{pH}$-meter using a suspension of $10 \mathrm{~g}$ of soil and water, with a soil solution ratio of 1:5. The carbon content was assessed using the Walkley-Black method (Nelson \& Sommers 1996).

\section{Abundance of edaphic microarthropods}

The number $(\mathrm{N})$ of microarthropods in each taxon was expressed as $\mathrm{Nm}^{-2}$ and then normalized as $\ln x+1$ (Jongman et al. 1995, Frampton et al. 2000).

In each plot, the average number of microarthropods was computed from the soil samples ( 3 per plot). Then, in each sampling area $(\mathrm{A}, \mathrm{B}, \mathrm{C}, \mathrm{D}$ and control $\mathrm{E})$, the mean number of microarthropods was estimated using soil samples from two plots per area.

\section{Statistical analysis}

\section{Effect of fire on edaphic microarthropod abundances}

The effect of fire on the microarthropod community was assessed with univariate and multivariate analysis of variance (ANOVA) using the PAST Programme ver. 2.17 (Hammer et al. 2001). In the area burned in 2012 (D), differences in edaphic microarthropod abundances in relation to time after fire (10 days, three months, five months) and to the control were investigated using one-way ANOVA.

A $t$-test was used to determine whether the abundances of individuals were significantly different in the different sampling seasons and years from fires in areas A, B, C and E.

The non-parametric Kruskal-Wallis test (Kruskal \& Wallis 1952) was used to evaluate differences in edaphic microarthropod abundance between sampling areas. In case of statistically significant differences, the Mann-Whitney post-hoc comparison test was used and the Bonferroni correction applied (Bonferroni 1935, 1936).

Variations in the abundance of the edaphic microarthropod community data between areas burned once, twice and not burned were investigated using Principal Component Analysis (PCA - Davis 1986, Harper 1999), which was conducted on a rectangular matrix of abundance (sample area $\times$ ta- xon) of each microarthropod taxon. To evaluate the number of informative axes, a bootstrap resampling technique with 1000 replicates was used (Jackson 1993). The significance of the eigenvector coefficients was evaluated by determining the $95 \%$ confidence limits.

The SIMPER analysis (Clarke 1993) using the Bray-Curtis similarity measure was applied to quantify the contribution of each taxon to the dissimilarity between groups of samples. Then, the groups of taxa that most contributed to the dissimilarity were checked using the Kruskal-Wallis test to assess whether fire influenced the increase and/or decrease in density of these groups.

Linear regression analysis was used to investigate the relationship between physical (carbon content, moisture and temperature) and chemical $(\mathrm{pH})$ soil characteristics and the abundance of edaphic microarthropods for all sampling seasons.

\section{Biodiversity of the edaphic microarthro- pod community}

Biodiversity of the edaphic microarthropod community was evaluated using Shannon's index, the evenness index and Simpson's index.

Shannon's index (Shannon \& Weaver 1962) was based on the number of microarthropods in a taxon and the total number of individuals in a sample (Magurran 1988). The evenness index was calculated using the Pielou's index (Pielou 1984), which shows how the taxa are equally abundant (Magurran 1988). Simpson's index (Simpson 1949), which describes the variance in the distribution of specific abundances (Magurran 2004), was used to assess the dominance of taxa.

The Kruskal-Wallis test was applied to compare the biodiversity indexes between the different areas and sampling seasons.

\section{Results}

Intermediate- and long-term fire effects on edaphic microarthropod abundances

To assess the intermediate- and long-term effects of fire on edaphic microarthropod abundance, data for the areas burned in 2001 (A), in 2009 (B) and in 2001 and 2009 (C) were compared with the control (E). The total number of soil microarthropod taxa (Tab. $\mathrm{S} 1$ in Appendix 1) was 22 in the control area, 22 in the area burned only in 2001 (A) and 20 in the area burned only in 2009 (B). In the area burned twice, 23 taxa were recorded in sub-area $\mathrm{C} 1$ and 19 taxa were recorded in sub-area $\mathrm{C} 2$. The highest number of individuals $\left(\mathrm{Nm}^{-2}\right)$ was found in the control (sampling date: Autumn 2011), while the lowest number was found in sub-area $\mathrm{C} 2$ (sampling date: Spring 2011 - Fig. 3).

Linear regression analysis of the micro- 
arthropod abundances and the chemical and physical soil characteristics did not show significant relationships. Only the sampling area burned in 2012 showed a significant linear regression $(\mathrm{p}=0.01)$ between abundance and carbon content, with a coefficient of determination of 0.69 .

In all cases, Acari and Collembola were the dominant taxonomic groups. In the control area, Acari accounted for $43 \%$ of the total number, and in the burned areas they exceeded $50 \%$ in all cases. Collembola accounted for approximately $40 \%$ of the total number in the areas $\mathrm{C} 1$ and $\mathrm{C} 2$.

The $t$-test showed that the total abundances did not differ significantly between sampling seasons and between fire years, while significant differences were detected after the Kruskall-Wallis test between the abundances in the control area and those in the areas burned once and twice (A, B and C), with an $\mathrm{Hc}$ of $18.26(\mathrm{df}=4, \mathrm{p}<0.001)$. In the area burned in 2009 (B) and in the sub-areas burned twice in 2001 and 2009 (C), microarthropod abundances were significantly lower (post-hoc Mann-Whitney test: p < 0.01 ). Microarthropod abundances in B and $\mathrm{C}$ were significantly different from those found in the area burned in 2001 (A). In contrast, area A did not significantly differ from the control $(p=0.6)$. In sub-area $\mathrm{C} 1$, the repeated passage of fire significantly influenced all edaphic microarthropod biodiversity indexes, i.e., the equitability of the proportional abundance of species (evenness $\mathrm{p}=0.046$ ), the species richness (Shannon $\mathrm{p}$ $=0.002)$ and the dominance (Simpson $\mathrm{p}=$ 0.012 ); however, in sub-areas $\mathrm{C} 1$ and $\mathrm{C} 2$, we found significant differences only for the Shannon's index ( $p=0.025$ - Tab. 3$)$.

The multivariate PCA also showed that the repeated passage of fire can play an important role in influencing the abundance of microarthropod community, some taxa being affected more than others. Overall, the first two principal components accounted for $41 \%$ of total variance in the edaphic microarthropod abundance; eigenvalues for the first and second PC axes were 29.16 and 9.63, respectively (Fig. 4). The first PC axis clearly reflected a gradient of fire disturbance. Indeed, data from the control area and from that burned in 2001 (A) all showed large PC1 scores (right side of Fig. 4), whereas the areas $\mathrm{C} 1$ and $\mathrm{C} 2$ (burned twice) and $\mathrm{B}$ (burned in 2009) tended to group on the left, except for three samples taken in 2012. $\mathrm{PC} 1$ was mainly related to the abundance of Symphyla, Diplopoda and Pseudoscorpionida, while PC2 was associated with the abundance of Diptera (adults and larvae), Hymenoptera (excluded ants) and Psocoptera. In fact, a remarkable average dissimilarity between the total abundance in the control and in areas $\mathrm{C} 1$ and $\mathrm{C} 2(35 \%$ and $40 \%$, respectively) was found using the SIMPER

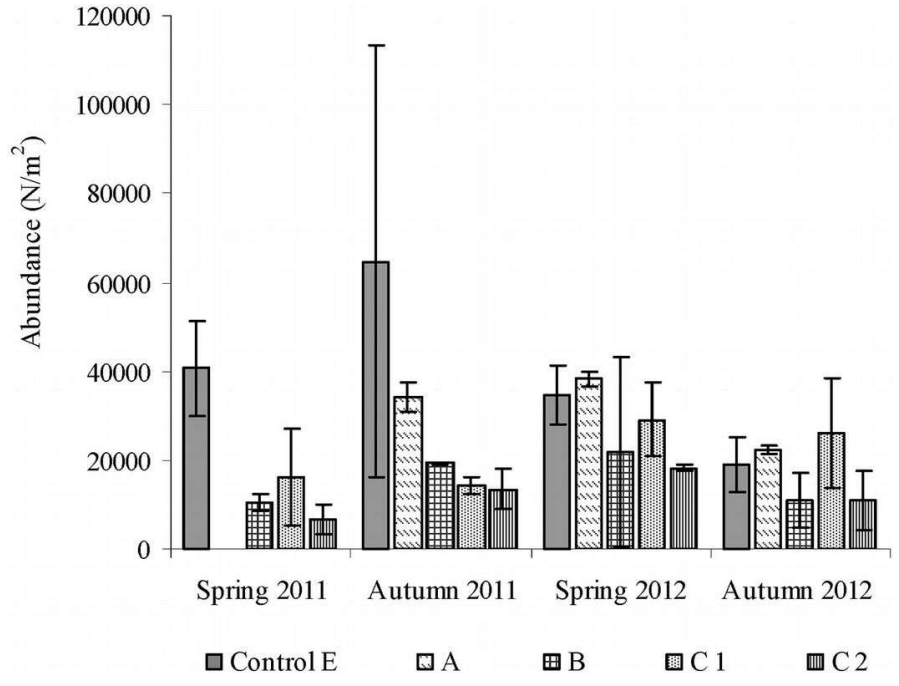

Fig. 3 - Abundance of microarthropods recorded in forest areas burned once or twice and after the intermediate- and long-term after fire. Error bars represent the standard deviation. (A): area burned in 2001; (B): area burned in 2009; (C): area burned in 2001 and in 2009; (E): control area.

Tab. 3 - Biodiversity indexes ( \pm standard deviation) of edaphic microarthropod communities recorded in each treatment and results of the Kruskall-Wallis test $(\mathrm{Hc}, \mathrm{df}=4)$ for differences between the control (E) vs. the areas burned once (A and B), and $v s$. the areas burned twice $(\mathrm{C} 1$ and $\mathrm{C} 2)$. Significant differences after the Mann-Whitney test are indicated. $\left({ }^{*}\right): \mathrm{p}<0.05$; $\left({ }^{* *}\right): \mathrm{p}<0.01$; (ns): not significant; (A); area burned in 2001; (B): area burned in 2009; $(\mathrm{C} 1$, $\mathrm{C} 2)$ : areas burned in 2001 and in 2009.

\begin{tabular}{lccc}
\hline Areas & Shannon's Index & Simpson's Index & Evenness Index \\
\hline E & $1.3 \pm 0.2^{\text {ns }}$ & $0.6 \pm 0.1$ & $0.5 \pm 0.1$ \\
A & $1.2 \pm 0.1^{\text {ns }}$ & $0.6 \pm 0.0^{\text {ns }}$ & $0.4 \pm 0.1^{\text {ns }}$ \\
B & $1.2 \pm 0.1^{\text {ns }}$ & $0.6 \pm 0.0^{\text {ns }}$ & $0.5 \pm 0.0^{\text {ns }}$ \\
C1 & $0.9 \pm 0.2^{* *}$ & $0.5 \pm 0.1^{*}$ & $0.4 \pm 0.1^{*}$ \\
C2 & $1.1 \pm 0.2^{*}$ & $0.6 \pm 0.1^{\text {ns }}$ & $0.5 \pm 0.0^{\text {ns }}$ \\
\hline Kruskal-Wallis Hc & $15.82^{* *}$ & $9.22^{*}$ & $8.54^{\text {ns }}$ \\
\hline
\end{tabular}

procedure. The most influenced taxonomic groups were Diplopoda, Thysanoptera, Pseudoscorpionida and Symphyla. Three years after fire, the difference between abundances in the control $\mathrm{E}$ and the area burned in 2009 (B) was $27 \%$, the most affected taxa being Thysanoptera, Symphyla and Pseudoscorpionida. The abundances of Symphyla and Pseudoscorpionida were significantly reduced (Kruskal-Wallis test, $\mathrm{p}<0.001$ ) both in $\mathrm{B}$ and $\mathrm{C}$ following fire, whereas the num-

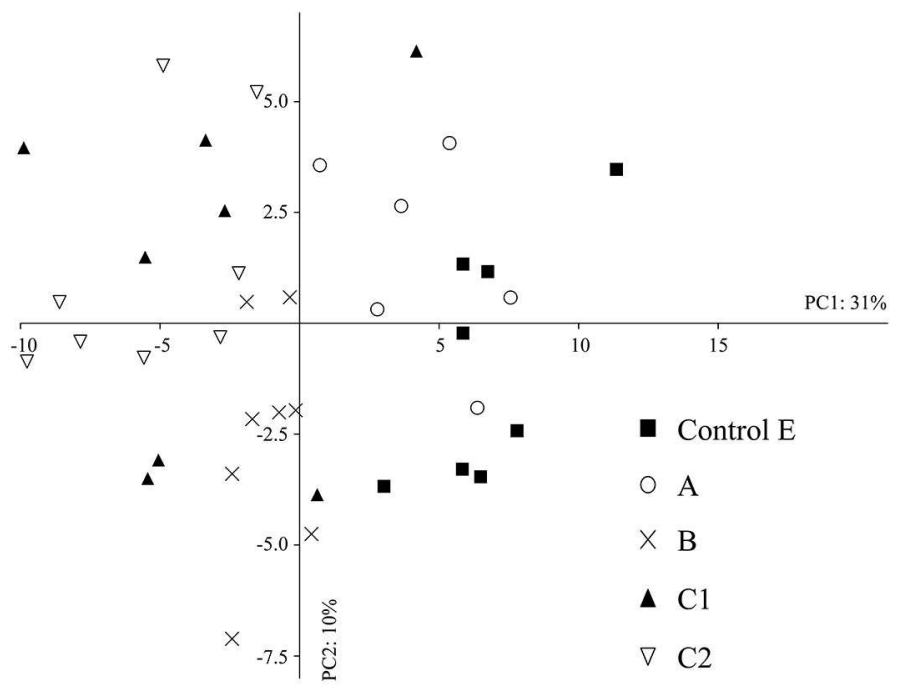

ber of Thysanoptera decreased in all areas affected by fire $(\mathrm{A}, \mathrm{B}, \mathrm{C})$ with $\mathrm{p}<0.001$. The number of Diplopoda was significantly reduced in the area burned twice $(\mathrm{C} 1$ and $\mathrm{C} 2, \mathrm{p}<0.001$ - Tab. 4).

\section{Short-term fire effect on microarthropod abundance}

The short-term fire effect on microarthropod abundance was assessed using data from the area burned in March 2012 (D). As com-

Fig. 4 - Principal component analysis (PCA) in the intermediate- and longterm after fire. (A): area burned in 2001; (B): area burned in 2009; (C): area burned in 2001 and in 2009; (E) control area. 
Tab. 4 - Abundance $\left(\mathrm{N} \mathrm{m}^{-2} \pm\right.$ standard deviation) of the main sol microarthropods recorded in each treatment and results of the Kruskall-Wallis test $(\mathrm{Hc})$ for differences between the control (E) vs. the areas burned once (A and B), and vs. the areas burned twice (C1 and C2). Significant differences after the Mann-Whitney test are indicated. $(* * *): p<0.001$; (ns): not significant.

\begin{tabular}{lcccc}
\hline Areas & Pseudoscorpionida & Symphyla & Thysanoptera & Diplopoda \\
\hline E & $141 \pm 97$ & $946 \pm 608$ & $592 \pm 835$ & $271 \pm 246$ \\
A & $78 \pm 89^{\text {ns }}$ & $17 \pm 31^{\text {ns }}$ & $6 \pm 13^{* * *}$ & $200 \pm 343^{\text {ns }}$ \\
B & $17 \pm 31^{* * *}$ & $304 \pm 217^{* * *}$ & $42 \pm 71^{* * *}$ & $146 \pm 232^{\text {ns }}$ \\
C1 & $12 \pm 25^{* * *}$ & $17 \pm 31^{* * *}$ & $4 \pm 12^{* * *}$ & $0 \pm 00^{* * *}$ \\
C2 & $0 \pm 0^{* * *}$ & $92 \pm 94^{* * *}$ & $8 \pm 15^{* * *}$ & $13 \pm 35^{* * *}$ \\
\hline Kruskal-Wallis Hc & $24.07^{* * *}$ & $26.53^{* * *}$ & $23.23^{* * *}$ & $20.32^{* * *}$ \\
\hline
\end{tabular}

pared with the control, a reduction of the number of taxa by 7-, 17- and 14-fold was observed in this area after ten days, three months and five months after fire, respectively (Tab. S1 in Appendix 1). Ten days after fire, the total number of microarthropods was 13633 , while 8316 and 16649 individuals were counted after three and five months, respectively (Fig. 5).

Even at such a short time after fire, there was no significant relationship between the

abundance of edaphic fauna and soil moisture and temperature. The decrease in carbon content in the first five months after fire showed a significant direct relationship to the number of microarthropods, whereas the relationship between $\mathrm{pH}$ and the abundance of soil fauna was not significant.

After the 2012 fire, Acari and Collembola were the most represented taxonomic groups in the intermediate- and long-term after fire. Ten days after fire, their percentages were

Fig. 5 - Abundance of microarthropods recorded in the short-term after fire. Error bars represent the standard deviation. Sampling date:

March, June and

September 2012

(D): area burned in

2012; (E): control area.

Fig. 6 - Principal component analysis (PCA) in the shortterm after fire. (D): area burned in 2012;

(E): control area.
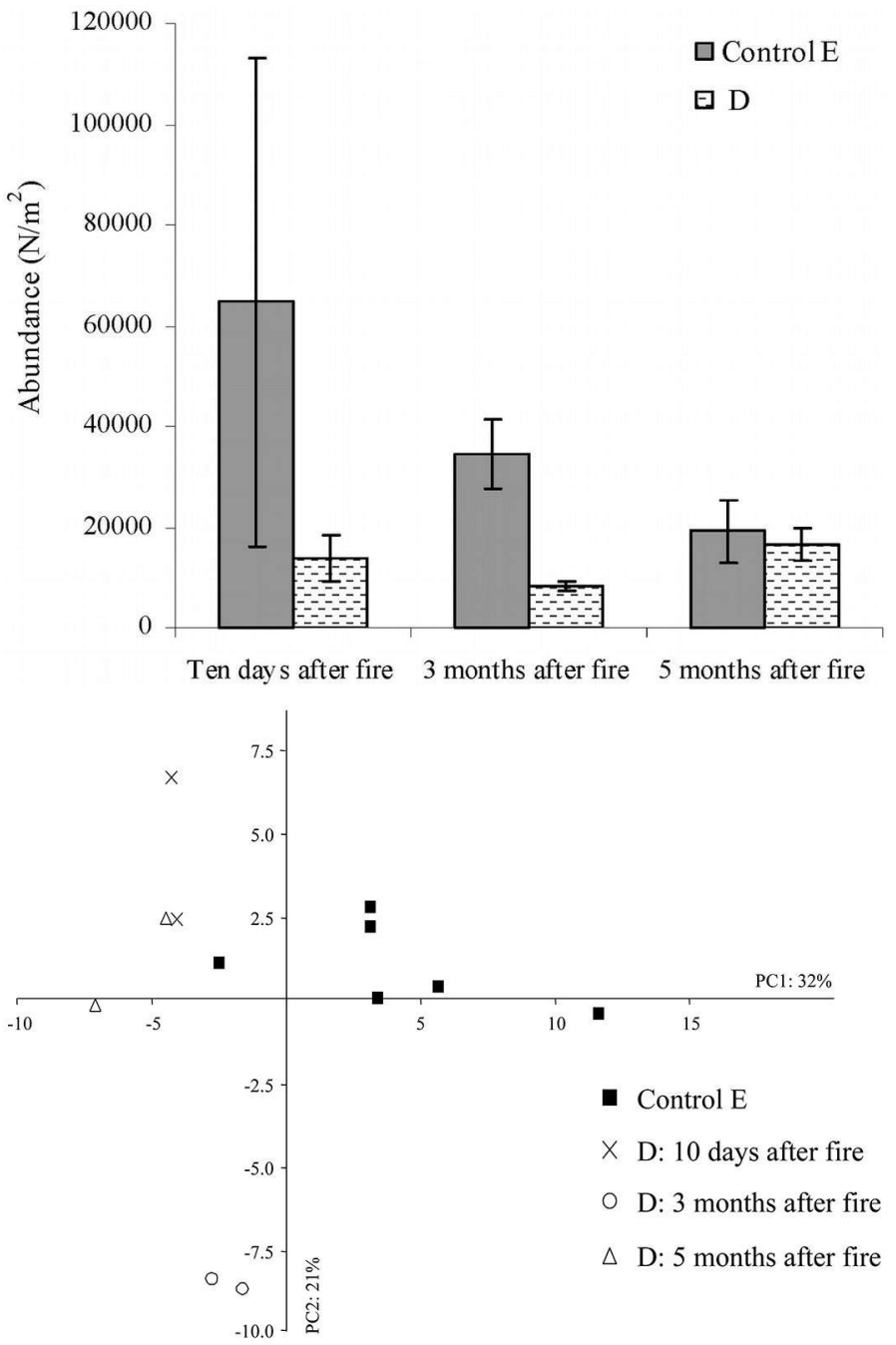

very high, with Acari and Collembola accounting for $81 \%$ and $5 \%$ of all microarthropods, respectively. After three months, the percentage of Acari was still high (72\%), but after five months, their abundance returned to values comparable with those of the control.

The $t$-tests confirmed that the abundance of individuals did not differ significantly five months after fire, and the ANOVA showed a significant decrease in edaphic microarthropod abundance between the control area and the area burned in $2012(\mathrm{~F}=10.87, \mathrm{p}<0.001)$.

The first two PC axes accounted for $53 \%$ of the total variation in the dataset (PC1: 32\%, PC2: 21\% - Fig. 6). The eigenvalues for the first axis and second axis were 29.09 and 19.53, respectively. Samples from the unburned area (E) showed large PC1 scores, grouping to the rightmost part of the biplot of Fig. 6 (except for the soil sample taken in the autumn 2012), while those from the area burned in 2012 were located to the left. The soil samples taken three months after fire appear clustered together in the negative semiaxis of both components (PC1, PC2), indicating a dramatic effect of fire on the abundance of the edaphic microarthropod community. PC1 was mostly related to the abundance of both Coleoptera and Diptera larvae, Diplura, Diplopoda, Symphyla and Pseudoscorpionida, whereas PC2 was mainly associated to the abundance of Pseudoscorpionida, Diptera larvae, ants and Symphyla.

The SIMPER analysis highlighted a high dissimilarity percentage between the control and the burned area three months after fire (31\%), decreasing to $28 \%$ after five months. Symphyla, Pseudoscorpionida, the larvae of Coleoptera and ants were the most affected microarthropods three months after fire, but after five months the Diplopoda and Pseudoscorpionida were the most reduced taxa. Immediately after fire (10 days), the dissimilarity was $28 \%$ due to the non-significant reduction ( $p>0.05)$ in the number of Diptera, Diplura and Symphyla larvae. The density of Pseudoscorpionida was significantly reduced ten days after fire (Kruskal-Wallis test: $\mathrm{p}<$ 0.05 ), and we did not find this taxonomic group in the soil sampled three and five months after fire. Biodiversity, as expressed by the Shannon, evenness and Simpson indexes, did not show significant differences after Kruskal-Wallis test between the control area $\mathrm{E}$ and the area burned in 2012 (ten days, three months and five months after fire).

\section{Discussion}

As often occurs in wildfire research, we had limited control over our experimental design; in particular, no replicates in other wildfire areas were available. Nonetheless, studying wildfires may provide critical information that can be difficult to obtain from experimental burns, since wildfires typically 
occur under more extreme conditions (Raymond \& Peterson 2005). To overcome this limit, sampling was repeated three times on two plots, with three samples per plot.

Our results show that fire in maritime pine forests significantly affects edaphic microarthropod communities, both in the mediumto long-term and in the short-term after fire. Repeated and frequent fires in the same area (in this case, two fires over a period of eight years) had produced significant changes in the soil fauna.

Similar studies carried out in different forest habitats and after different intervals of time after fire have shown a reduction in soil arthropod abundance (Athias-Binche 1987 Broza et al. 1993, Koponen 1995, Broza \& Izhaki 1997, York 1999, Tajovský 2002, Buddle et al. 2006, Bezkorovainaya et al. 2007, Malmström et al. 2008). According to other authors, the arthropod community can show some resilience to fire (Majer 1980 , Majer 1984, Abbott 1984, Paquin \& Coderre 1997, Moretti et al. 2004, Moretti et al 2006, Murunga 2013).

After fire, the most abundant groups are usually mites and springtails (Broza et al 1993, Coleman \& Rieske 2006). In our study, changes in edaphic communities caused by wildfire were observed in relation to both time after fire and fire frequency. Microarthropod communities tended to recover within 10 years since burning. In the area burned twice (2001 and 2009), the most sensitive taxonomic groups were Pseudoscorpionida, Symphyla, Thysanoptera and Diplopoda, which remarkably decreased their abundance. In the short-term after fire (five months), Diplopoda were significantly reduced, while the total number of centipedes, Araneidae and Isopoda was not influenced by fire. Similarly, Abbott (1984) found that millipedes were the least abundant taxonomic group one year after fire in the Jarrah Forest (western Australia). In our study, the Diplopoda community recovered two years after fire. Furthermore, a study on centipedes in the Mediterranean region (Trucchi et al 2009) showed a reduction of the abundance of this taxon due to surface fire, while the centipede community composition did not seem to be affected by crown fire.

Our results show that the most sensitive taxonomic groups in the short-term after fire included organisms that play an active role in the soil only during their larval stage (Coleoptera and Diptera larvae), as well as Pseudoscorpionida. Probably 10 days after fire, soil conditions were not suitable for the development of Diptera and Coleoptera larvae, which repopulated the soil later. Pseudoscorpionida were the only taxonomic group affected by fire both two years after fire and in areas burned twice. They were also influenced in the short-term, confirming their high sensitivity to fire, as observed by
York (1999) in Australian blackbutt forests. In our study, fire affected some taxonomic groups (Diplopoda, Symphyla, Chilopoda, Protura, Diplura, Pseudoscorpionida) more than others which appeared more resilient (Isoptera and Blattoidea), as revealed by the results of the PCA. Some of these organisms, e.g., Symphyla, generally characterize undisturbed soil (Bedano et al. 2006) where they may deeply influence the soil ecosystem regardless of their abundance (Lagerlöf \& Scheller 1989). It has been reported that the Chilopoda community undergoes deep structural changes after fire (Trucchi et al. 2009). Their observed decrease after fire was not significant in this study, likely because these organisms usually migrate into the deeper soil layers to find more suitable conditions for survival (Sgardelis et al. 1995).

The principal component analysis carried out revealed remarkable differences in the soil microarthropod community between burned and unburned areas both in the medium- to long- and in the short-term after fire. In the long term, the effects of fire on such communities and their microhabitat are mainly indirect, probably due to changes in forest cover. Ten year after fire, the numerical strength of microarthropods was comparable to that observed in the unburned area, likely due to the local restoration of suitable environmental conditions in a natural-regenerated stand of maritime pine and broadleaves re-established after fire.

In the short-term, the effect seems mainly direct, e.g., soil microarthropods were probably killed by fire and heat, rather than by indirect effects, as pointed out by Malmström et al. (2008) for mites, springtails and Protura. Five months after fire, the microarthropod communities had still not totally recovered compared with the control area.

The biodiversity of the edaphic microarthropod communities showed significant changes in the area burned twice, as revealed by the stronger influence of fire on species richness than on equitability and dominance. In the short-term after fire, biodiversity indexes were comparable to the situation before fire occurrence.

Even if the abundance of soil microarthropods is often correlated to soil conditions (Won Kim \& Jung 2008), we did not detect significant relationships between microarthropod density and soil chemical and physical characteristics, both in the intermediatelong term and in the short-term after fire, except for the decrease of carbon content in the first five months after fire. The increase in soil alkalinity caused by ash just after fire (Saarsalmi et al. 2001, Khanna et al. 1994), did not seem to affect edaphic microarthropod abundance. The observed restoration of soil $\mathrm{pH}$ to the pre-fire level within five months is in agreement with the results by Jalaluddin (1969). According to Fernandez et al. (1997), the stored carbon content, which decreased in the first three months after fire, returned to the control level two years later, and it did not affect the abundance of soil microarthropods. According to Kautz et al. (2006), the observed decrease in microarthropod abundance in the short-term after fire can be determined by changes in the immediate supply of food rather than by soil chemical parameters, such as carbon or $\mathrm{pH}$.

It is worth to notice that only high taxonomic levels (Orders or Families) were considered in this study. Indeed, the analysis of the microarthopod biocoenosis at lower taxonomic levels could highlight further differences between genera or species. Further studies are needed to investigate such possible differences.

\section{Conclusions}

Monitoring the soil microarthropod community is an important tool for better understanding the effects of fire on forest ecosystems. Our results show that a more efficient assessment of fire impacts could be achieved by surveying all microarthropod taxa rather than monitoring only chemical or physical soil parameters. Edaphic microarthropods are effective bio-indicators of the environmental change; however, the interactions of biological, chemical and physical aspects should be always monitored to obtain a broader picture of soil forest ecosystems.

After a wildfire, the natural evolution of forest structure and composition can also affect soil components, leading to habitat conditions unsuitable for the microarthropod community. Some taxonomic groups (e.g., Pseudoscorpionida) are more sensitive to fire and/or repeated fire passes than others, and this can produce long-lasting transformations of the microarthropod community. In our study, such transformations were still evident two years after the last fire.

Despite the number of studies on the soil microarthropod communities after fire in the literature, their sampling methods are often different, thereby their results are often difficult to compare. Moreover, usually only a limited number of taxonomic groups are considered in different forest habitats and after different fire conditions. The analysis of whole microarthropod communities, such as that carried out in this study, are much fewer and need further research effort. To this regard, it would be useful to study the relationship between microarthropods and other soil organisms (e.g., fungi, microorganisms) to throw light on the influence of fire on the soil ecosystem and trophic chains, as previously reported by Murunga (2013) for soil arthropods in Kenya.

Our work indicates that monitoring the effects of fire on the whole edaphic microarthropod community in forest habitats can 
provide useful information for better management and rehabilitation of forest ecosystems impacted by fire.

\section{Acknowledgements}

We wish to thank Dr. Elena Perilli of the Italian National Forest Service (Corpo Forestale dello Stato) for supporting this research in the Montefalcone National Nature Reserve.

\section{References}

Abbott I (1984). Changes in the abundance and activity of certain soil and litter fauna in the Jarrah Forest of western Australia after a moderate intensity fire. Australian Journal of Soil Research 22: 463-469. - doi: 10.1071/SR9840463

Athias-Binche F (1987). Regeneration pattern of Mediterranean ecosystems after fire: the case of some soil arthropods: uropodid mites. Vie et Milieu 37: 39-52.

Bastida F, Zsolnay A, Hernández T, Garcia $C$ (2008). Past, present and future of soil quality indices: a biological perspective. Geoderma 147 159-171. - doi: 10.1016/j.geoderma.2008.08.007 Bedano JC, Cantù MP, Doucet ME (2006). Soil springtail (Hexapoda: Collembola), symphylans and pauropods (Arthopoda: Myriapoda) under different management system in agroecosystem of subhumid Pampa (Argentina). European Journal of Soil Biology 42: 107-119. - doi: 10.1016/ j.ejsobi.2005.11.004

Berlese A (1905). Apparecchio per raccogliere presto ed in gran numero piccoli Artropodi [Tool for quickly collecting small arthropods in large number]. Redia 2: 85-90. [in Italian]

Bezkorovainaya IN, Krasnoshchekova EN, Ivanova GA (2007). Transformation of soil invertebrate complex after surface fires of different intensity. Biology Bulletin 34: 517-522. - doi: 10.1134/S1062359007050159

Blondel J, Aronson J, Bodiou JY, Boeuf G (2010). The Mediterranean region: biological diversity in space and time. Oxford University Press, New York, USA, pp. 376. [online] URL: http://library.wur.nl/WebQuery/clc/1929515

Bonferroni CE (1935). Il calcolo delle assicurazioni su gruppi di teste [The calculation of the insurance on groups of heads]. In: "Studi in onore del Professore Salvatore Ortu Carboni". Bardi ed., Rome, Italy, pp. 13-60. [in Italian]

Bonferroni CE (1936). Teoria statistica delle classi e calcolo delle probabilità [Statistical theory of classes and probability]. Pubblicazioni dell'Istituto Superiore di Scienze Economiche e Commerciali di Firenze 8: 3-62. [in Italian]

Broza M, Izhaki I (1997). Post-fire arthropod assemblages in Mediterranean forest soils in Israel. International Journal of Wildland Fire 7: 317325. - doi: 10.1071/WF9970317

Broza M, Poliakov D, Weber S, Izhaki I (1993). Soil microarthropods on post-fire pine forest on Mount Carmel, Israel. Water Science and Technology 27: 533-538. [online] URL: http://www.i waponline.com/wst/02707/wst027070533.htm Buddle CM, Langor DW, Pohl GR, Spence JR
(2006). Arthropod responses to harvesting and wildfire: implications for emulation of natural disturbance in forest management. Biological Conservation 128: 346-357. - doi: 10.1016/j.biocon.2005.10.002

Camann MA, Gillette NE, Lamocha L, Mori SR (2008). Response of forest soil Acari to prescribed fire following stand structure manipulation in the southern Cascade Range. Canadian Journal of Forest Research 38: 956-968. - doi: 10.1139/X07-241

Clarke KR (1993). Non-parametric multivariate analysis of changes in community structure. Australian Journal of Ecology 18: 117-143. - doi: 10.1111/j.1442-9993.1993.tb00438.x

Coleman TW, Rieske LK (2006). Arthropod response to prescription burning at the soil-litter interface in oak-pine forests. Forest Ecology and Management 233: 52-60. - doi: 10.1016/j.foreco.2006.06.001

Cuchta P, Miklisová D, Kováč L (2012a). European montane spruce forests 2 years after disturbance by fire. Annals of forest Science 69 : 8192. - doi: 10.1007/s13595-011-0114-y

Cuchta P, Miklisová D, Kováč L (2012b). The impact of disturbance and ensuing forestry practices on Collembola in monitored stands of windthrown forest in the Tatra National Park (Slovakia). Environmental Monitoring and Assessment 185 (6): 5085-5098. - doi: 10.1007/s1 0661-012-2927-z

Dale VH, Beyeler SC (2001). Challenges in the development and use of ecological indicators. Ecological Indicators 1: 3-10. - doi: 10.1016/S1 470-160X(01)00003-6

Davis JC (1986). Statistics and data analysis in geology. Wiley, New York, USA, pp. 646.

DeBano LF, Neary DG, Ffolliott PF (1998). Fire Effects on Ecosystems. John Wiley \& Sons, New York, USA, pp. 333. [online] URL: http://books. google.com/books?id=cFxtriC2EDkC

Dress WJ, Boerner RE (2003). Patterns of microarthropod abundance in oak-hickory forest ecosystems in relation to prescribed fire and landscape position. Pedobiologia 48: 1-8. - doi: 10.1016/j.pedobi.2003.03.001

Fernandez I, Cabaneiro A, Carballas T (1997). Organic matter changes immediately after a wildfires in an atlantic forest soil and comparison with laboratory soil heathing. Soil Biology and Biochemistry 29: 1-11. - doi: 10.1016/S0038-07 17(96)00289-1

Frampton GK, Van Den Brink PJ, Gould PJL (2000). Effects of spring drought and irrigation on farmland arthropods in southern Britain. Journal of Applied Ecology 37: 865-883. - doi: 10.1046/j.1365-2664.2000.00541.x

García-Ruiz A (2001). Estudio de los efectos de un incendio sobre las poblaciones de miriàpodos [Study of the effects of fire on populations of miriapodes]. Ecología 15: 269-273. [in Spanish] Gillson L (2009). Landscape in time and space. Landscape Ecology 24: 149-155. - doi: 10.1007/ s10980-008-9315-7

Grabcizynska O, Olejniczak I, Predecka A, Russel S (2009). Short term effect of prescribed forest fire on soil mites. Short research contribution. Polish Journal of Ecology 57: 805-809.

Granström A (2001). Fire management for biodiversity in the European boreal forest. Scandinavian Journal of Forest Research 3: 62-.69. - doi: 10.1080/028275801300090627

Hadjibiros K (2001). Setting priorities for wildfire suppression policy in Greece, using a relation between year burned areas and recovery time. Global Nest: The International Journal 3: 37-43. [online] URL: https://www.ath.aegean.gr/gnest/ Journal/Vol3_No1/hadjibiros.pdf

Hammer O, Harper DAT, Ryan PD (2001). PAST: palaeontological statistics software package for education and data analysis. Palaeontologia Electronica 4: 9-9. [online] URL: http://www.uv. es/ pardomv/pe/2001_1/past/pastprog/past.pdf Harper DAT (1999). Numerical palaeobiology. Wiley, Chichester, UK, pp. 468.

Heneghan L, Bolger T (1998). Soil microarthropod contribution to forest ecosystem processes: the importance of observational scale. Plant and Soil 205: 113-124. - doi: 10.1023/A:100437491 2571

Huebner KR, Lindo Z, Hyperlink MJ (2012). Post-fire succession of collembolan communities in a northern hardwood forest. European Journal of Soil Biology 48: 59-65. - doi: 10.1016/j.ejso bi.2011.10.004

Jackson DA (1993). Stopping rules in principal components analysis: a comparison of heuristical and statistical approaches. Ecology 74: 22042214. - doi: 10.2307/1939574

Jalaluddin M (1969). Micro-organic colonization of forest soil after burning. Plant and Soil 30: 150-152. - doi: 10.1007/BF01885277

Jongman RHG, Ter Braak CJF, Van Tongeren OFR (1995). Data analysis in community and landscape ecology. Cambridge University Press, Cambridge, UK, pp. 299. [online] URL: http:// books.google.com/books?id=Oy8F3oVGPeIC

Karr JR (1991) Biological integrity: a long neglected aspect of water resource management. Ecological Applications 1: 66-84. [online] URL: http://www.jstor.org/stable/1941848

Kautz T, Lòpez-Fando C, Ellmer F (2006). Abundance and biodiversity of soil microarthropods influenced by different types of organic manure in a long-term field experiment in Central Spain. Applied Soil Ecology 33: 278-285. - doi: 10.101 6/j.apsoil.2005.10.003

Keeley JE (2009). Fire intensity, fire severity and burn severity: a brief review and suggested usage. International Journal of Wildland Fire 18: 116-126. - doi: 10.1071/WF07049

Khanna PK, Raison RJ, Falkiner RA (1994). Chemical properties of ash derived from Eucalyptus litter and its effects on forest soils. Forest Ecology and Management 66: 107-125. - doi: 10.1016/0378-1127(94)90151-1

Koponen S (1995). Postfire succession of soil arthropod groups in a subarctic birch forest. Acta Zoologica Fennica 196: 243-245.

Köppen W (1936). Das geographische System der Klimate [The geographic system of climates]. In: "Handbuch der Klimatologie" (Köppen W, Gei- 
ger R eds). IC, Berlin, Germany, pp. 44. [in German]

Kremen C (2005). Managing ecosystem services: what do we need to know about their ecology? Ecology Letters 8: 468-479. - doi: 10.1111/j.146 1-0248.2005.00751.x

Kruskal WH, Wallis WA (1952). Use of ranks in one-criterion variance analysis. Journal of the American Statistical Association 47: 583-621. doi: 10.1080/01621459.1952.10483441

Lagerlöf J, Scheller U (1989). Abundance and activity of Pauropoda and Symphyla (Myriapoda) in four cropping systems. Pedobiologia 33: 315321. [online] URL: http://cat.inist.fr/?aModele= afficheN\&cpsidt $=6676809$

Lussenhop J (1992). Mechanism of microarthropods-microbial interaction in the soil. Advances in Ecological Research 23: 1-33. - doi: 10.1016/ S0065-2504(08)60145-2

Magurran AE (1988). Ecological diversity and its measurement. Princeton University Press, New York, USA, pp. 192. [online] URL: http://pup. princeton.edu/titles/4238.html

Magurran AE (2004). Measuring biological diversity. Blackwell Sciences, Oxford, UK, pp. 215.

Majer JD (1980). Report on a study of invertebrates in relation to the Kojonup Nature Reserve Fire Management Plan. Departmental Technical Report, Western Australian Institute of Technology, Bentley, Australia, pp. 25. [online] URL: http://espace.library.curtin.edu.au/webclient/Stre amGate?folder_id $=0 \& d v s=1429550927152 \sim 849$

Majer JD (1984). Short term responses of soil and litter invertebrates to a cool autumn burn in Jarrah (Eucalyptus marginata) forest in Western Austalia. Pedobiologia 26: 229-247. [online] URL: http://cat.inist.fr/?aModele=afficheN\&cps $\mathrm{idt}=8846558$

Malmström A (2010). The importance of measuring fire severity - Evidence from microarthropod studies. Forest Ecology and Management 260 (1): 62-70. - doi: 10.1016/j.foreco.2010.04.0 01

Malmström A (2012). Life-history traits predict recovery patterns in Collembola species after fire: a 10 year study. Applied Soil Ecology 56: 35-42. - doi: 10.1016/j.apsoil.2012.02.007

Malmström A, Persson T, Ahlström K (2008). Effects of fire intensity on survival and recovery of soil microarthropods after a clear-cut burning. Canadian Journal of Forest Research 38 (9): 2465-2475. - doi: 10.1139/X08-094

Marshall VG (2000). Impacts of forest harvesting on biological process in northern forest soils. Forest Ecology and Management 133 (1-2): 43 60. - doi: 10.1016/S0378-1127(99)00297-2

Moreira F, Rego FC, Ferreira PG (2001). Temporal (1958-1995) pattern of change in a cultural landscape of northwestern Portugal: implications for fire occurrence. Landscape Ecology 16 (6): 557-567. - doi: 10.1023/A:1013130528470

Moretti M, Obrist MK, Duelli P (2004). Arthropod biodiversity after forest fires: winners and losers in the winter fire regime of the southern Alps. Ecography 27 (2): 173-186. - doi: 10.1111/ j.0906-7590.2004.03660.x
Moretti M, Duelli P, Obrist MK (2006). Biodiversity and resilience of arthropods communities after fire disturbance in temperate forests. Oecologia 149 (2): 312-327. - doi: 10.1007/s00442-00 6-0450-z

Murunga M (2013). Assessment of short term effects of soil arthropods in the Aberdare National Park Kenya. BSc dissertation, School of Biological Sciences, University of Nairobi, Kenya, pp. 28. [online] URL: http://www.academia.edu/41 33010/

Neary DG, Klopatek CC, DeBano LF, Ffolliott PF (1999). Fire effects on belowground sustainability: a review and synthesis. Forest Ecology and Management 122 (1-2): 51-71. - doi: 10.1016/S0 378-1127(99)00032-8

Nelson DW, Sommers LE (1996). Total carbon, organic carbon, and organic matter. In: "Methods of Soil Analysis: Part 3 - Chemical Methods" (Sparks DL, Page AL, Helmke PA, Loeppert RH, Soltanpour PN, Tabatabai MA, Johnston CT, Sumner ME eds). SSSA Book Series No. 5, Soil Science Society of America, Madison, WI, USA, pp. 961-1010. [online] URL: https://dl.sciencesocieties.org/publications/books /abstracts/sssabookseries/methodsofsoilan3/961/ preview

Nimis PL, Scheidegger C, Wolseley PA (2002). Monitoring with lichens - monitoring lichens. NATO Science Series vol. 7, Springer, The Netherlands, pp. 1-4. - doi: 10.1007/978-94-010-04 23-7_1

Nocentini S, Bottalico F, Faraoni L, Fiorentini S, Lisa C, Marchi E, Neri F, Paffetti D, Piemontese FP, Puletti N, Travaglini D (2011). Piano di gestione del consorzio forestale delle Cerbaie 20122026 [The forest management plan 2012-2026 of the Cerbaie forest consortium]. Università degli Studi di Firenze, Dipartimento di Economia, Ingegneria, Scienze e Tecnologie Agrarie e Forestali, Florence, Italy, pp. 34-36. [in Italian]

Norton RA (1985). Aspects of the biology and systematics of soil arachnids, particularly saprophagous and mycophagous mites. Quaestiones Entomologicae 21: 523-541.

Olivari S (2004). Morfologia, geologia e pedologia [Morphology, geology and soil science]. In: "La Riserva Naturale di Montefalcone: storia, ambiente e territorio" (Cappelli F, Cappelli V, Fabbrizzi F, Olivari S, Piussi P, Sbragia M, Stiavelli S eds). Tipografia La Grafica Pisana, Pisa, Italy, pp. 21-30. [in Italian]

Paquin P, Coderre D (1997). Deforestation and fire impact on edaphic insect larvae and other macroarthropods. Environmental Entomology 26 (1): 21-30. - doi: 10.1093/ee/26.1.21

Pausas JG (2004). Changes in fire and climate in the eastern Iberian Peninsula (Mediterranean Basin). Climatic Change 63 (3): 337-350. - doi: 10.1023/B:CLIM.0000018508.94901.9c

Pielou EC (1984). The interpretation of ecological data. Wiley-Interscience Publication, John Wiley and Sons, New York, USA, pp. 263.

Raymond CL, Peterson DL (2005). Fuel treatments alter the effects of wildfire in a mixedevergreen forest, Oregon, USA. Canadian Jour- nal of Forest Research 35 (12): 2981-2995. - doi: 10.1139/x05-206

Ream CH (1981). The effects of fire and other disturbances on small mammals and their predators: an annotated bibliography. Gen. Tech. Rep. INT-106, Intermountain Forest and Range Experiment Station, USDA Forest Service, Ogden, UT, USA, pp. 55. [online] URL: http://library. wur.nl/WebQuery/clc/148531

Roloff GJ, Mealey SP, Clay C, Barry J, Yanish C, Neuenschwander L (2005). A process for modeling short- and long-term risk in the southern Oregon Cascades. Forest Ecology and Management 211 (1-2): 166-190. - doi: 10.1016/j.for eco.2005.02.006

Saarsalmi A, Melkönen E, Piirainen S (2001). Effects of wood ash fertilization on forest soil chemical properties. Silva Fennica 35 (3): 355 368. - doi: 10.14214/sf.590

Santalla S, Salgado JM, Calvo L, Fernandez MMF (2002). Changes in the Carabidae community after a large fire in a Pinus pinaster stand. In: "Fire and Biological Processes" (Trabaud L, Pradon R eds). Backhuys Publishers, Leiden, The Netherlands, pp. 215-231.

Saulnier L, Athias-Binche F (1986). Modalités de la cicatrisation des écosystème méditerranéens aprés incendie: cas de certains arthropodes du sol 2. Les myriapodes édaphiques [Methods of recovering of Mediterranean ecosystem after fire: the case of some soil arthropods 2. Soil Myriapods]. Vie Milieu 36: 191-204. [in French]

Sbragia M (2004). Il clima. In: "La Riserva Naturale di Montefalcone: storia, ambiente e territorio" [The climate. In: "The Montefalcone natural reserve: history, environment and territory"] (Cappelli F, Cappelli V, Fabbrizzi F, Olivari S, Piussi P, Sbragia M, Stiavelli S eds). Tipografia La Grafica Pisana, Pisa, Italy, pp. 15-20. [in Italian]

Seastedt TR (1984). The role of microarthropods in decomposition and mineralization process. Annual Review of Entomology 29: 25-46. - doi: 10.1146/annurev.en.29.010184.000325

Seastedt TR, Crossley DA (1984). The influence of arthropods on ecosystems. BioScience 34: 157-161. - doi: 10.2307/1309750

Sgardelis SP, Pantis JD, Argyropoulou MD, Stamou GP (1995). Effects of fire on soil macroinvertebrates in a Mediterranean Phryganic ecosystem. International Journal of Wildland Fire 5: 113-121. - doi: 10.1071/WF9950113

Shannon CE, Weaver W (1962). The mathematical theory of communication. University of Illinois Press, Urbana, IL, USA.

Silveira JM, Barlow J, Louzada J, Mountinho P (2010). Factors affecting the abundance of leaflitter arthropods in unburned and thrice-burned seasonally-dry Amazonian forests. PloS ONE 5 (9): e12877. - doi: 10.1371/journal.pone.00128 77

Simpson EH (1949). Measurement of diversity. Nature 163: 688-688. - doi: 10.1038/163688a0 Spellerberg IF (1991). Monitoring ecological change. Cambridge Unviersity Press, Cambridge, UK, pp. 181-182. 
Striganova BR (2000). Locomotory and trophic activity of invertebrates as a factor of soil structure formation. Eurasian Soil Science 33: $1094-$ 1100. [online] URL: http://cat.inist.fr/?aModele= afficheN\&cpsidt $=800596$

Tajovský K (2002). Soil macrofauna (Diplopoda, Chilopoda, Oniscidea) in a pine forest disturbed by wild fire. In: Proceedings of the " $6^{\text {th }}$ Central European Workshop on Soil Zoology: Studies on soil fauna in Central Europe" (Tajovský K, Balik V, Pižl V eds). Ceské Budejovice (Czech Republic) 23-25 Apr 2001, pp. 227-232.

Thornthwaite CW (1948). An approach toward a rational classification of climate. Geographical Reviews 38: 55-94. - doi: 10.2307/210739

Trucchi E, Pitzalis M, Zapparoli M, Bologna MA (2009). Short-term effects of canopy and surface fire on centipede (Chilopoda) communities in a semi natural Mediterranean forest. Entomologica
Fennica 20: 129-138. [online] URL: http://www. researchgate.net/profile/Monica_Pitzalis/publication/228095265

Tüllgren A (1918). Ein sehr einfacher Ausleseapparat für terricole Tierfaunen [A simple tool for sampling soil fauna]. Zeitschrift für angewandte Entomologie 4: 149-150. [in German]

Vincent K, Moening K, Colter H (2009). Effects of annual fire on the litter fauna populations and soil compositions of an upland white-oak forest. Journal of Prairie Restoration Research 6: 17-20.

Wallwork JA (1983). Oribatei in forest ecosystem. Annual Review of Entomology 28: 109-130. doi: 10.1146/annurev.en.28.010183.000545

Wikars LO, Schimmel J (2001). Immediate effects of fire-severity on soil invertebrates in cut and uncut pine forests. Forest Ecology and Management 141: 189-200. - doi: 10.1016/S0378-1127 (00)00328-5
Won Kim J, Jung C (2008). Abundance of soil microarthropods associated with forest fire severity in Samcheok, Korea. Journal of Asia-Pacific Entomology 11: 77-81. - doi: 10.1016/j.aspen.2008.05.003

York A (1999). Long-term effects of frequent lowintensity burning on the abundance of litterdwelling invertebrates in coastal blackbutt forests of southeastern Australia. Journal of Insect Conservation 3: 191-199. - doi: 10.1023/A:1009 643627781

\section{Supplementary Material}

Appendix 1 - Taxa and their relative abundance ( \pm standard deviation) recorded in each treatment.

Link: Lisa_1404@suppl001.pdf 